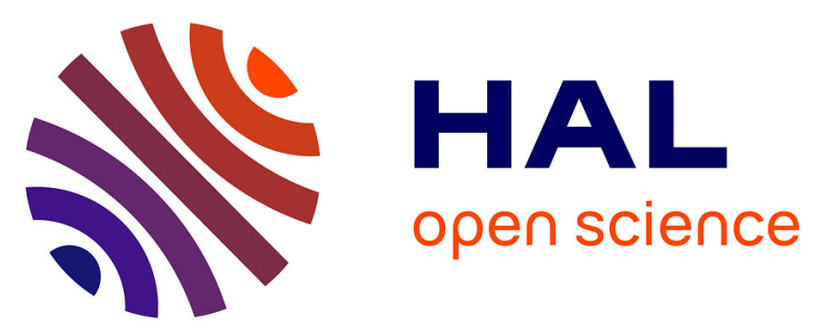

\title{
Structural and electrochemical studies of functionalization of reduced graphene oxide with alkoxyphenylporphyrin mono- and tetra- carboxylic acid: application to DNA sensors
}

Yaqiong Wang, Zouhour Hsine, Helene Sauriat-Dorizon, Rym Mlika, Hafsa Korri-Youssoufi

\section{To cite this version:}

Yaqiong Wang, Zouhour Hsine, Helene Sauriat-Dorizon, Rym Mlika, Hafsa Korri-Youssoufi. Structural and electrochemical studies of functionalization of reduced graphene oxide with alkoxyphenylporphyrin mono- and tetra- carboxylic acid: application to DNA sensors. Electrochimica Acta, 2020, 357, pp.136852. 10.1016/j.electacta.2020.136852 . hal-03066379

\author{
HAL Id: hal-03066379 \\ https://hal.science/hal-03066379
}

Submitted on 4 Jan 2021

HAL is a multi-disciplinary open access archive for the deposit and dissemination of scientific research documents, whether they are published or not. The documents may come from teaching and research institutions in France or abroad, or from public or private research centers.
L'archive ouverte pluridisciplinaire HAL, est destinée au dépôt et à la diffusion de documents scientifiques de niveau recherche, publiés ou non, émanant des établissements d'enseignement et de recherche français ou étrangers, des laboratoires publics ou privés. 


\title{
Structural and electrochemical studies of functionalization of reduced graphene oxide with alkoxyphenylporphyrin mono- and tetra- carboxylic acid: application to DNA sensors
}

\author{
Yaqiong Wang $_{*}^{a}$, Zouhour Hsine $e^{a, b}+$ Helene Sauriat-Dorizon ${ }^{a}$, Rym Mlika $^{b}$ and Hafsa Korri-Youssoufi ${ }^{a} *$ \\ ${ }^{a}$ Université Paris-Saclay, CNRS, Institut de Chimie Moléculaire et des Matériaux d'Orsay (ICMMO), ECBB, \\ Bât 420, 2 Rue du Doyen Georges Poitou, 91400, Orsay, France \\ ${ }^{\mathrm{b}}$ Laboratory of Interfaces and Advanced Materials, Faculty of Sciences of Monastir , University of Monastir, \\ 5019 Monastir, Tunisia
}

\begin{tabular}{l} 
A R T I C L E I N F O \\
\hline Article history: \\
Received 00 December 00 \\
Received in revised form 00 January 00 \\
Accepted 00 February 00
\end{tabular}

Keywords:

Tetraphenylporphyrin

Reduced graphene oxide

Nanomaterial

DNA

biosensor

\begin{abstract}
A B S T R A C T
Association of graphene with conjugated organic macromolecules presents an interest in various applications. Here, we study the chemical and electrical properties of nanomaterials which combine the features of chemical reduced graphene oxide (CRGO) and its modification with tetrabutyloxyphenylporphyrins bearing a mono- or tetra-carboxylic functions. The hybrid nanomaterials are characterized through different techniques including UV-visible, FT-IR, Raman spectroscopy, MEB and SEM. Their electrochemical properties are studied by cyclic voltammetry (CV) with inner sphere and outer sphere redox markers as well as electrochemical impedance spectroscopy (EIS). The overall results support the formation of strong interactions between porphyrins and CRGO. Furthermore, we highlight the relationship of structural and electronic properties of porphyrins on the resulted composite. Thus, we demonstrate that modified porphyrins with alkoxy and carboxyl groups improve the dispersion of CRGO and have positive effects on their electronic properties in particular the electron transfer ability. These nanocomposites open new opportunities for their application in biosensors devices and the detection of DNA of M. Tuberculosis was demonstrated with LOD at attomolar range and an ability to discrimination of M. tuberculosis strand from mutated in PCR sample.
\end{abstract}

(C) $\operatorname{xxxxxxx.~Hosting~by~Elsevier~B.V.~All~rights~reserved.~}$

*Corresponding authors: E-mail hafsa.korri-youssoufi@universite-paris-saclay.fr (H. Korri-Youssoufi) (+33) 01-69-15-74-40.

† Present address:Yaqiong Wang: Guangdong Key Lab of Nano-Micro Materials Research, School of Chemical Biology and Biotechnology Shenzhen Graduate School, Peking University, 518055 Shenzhen, China 


\section{Introduction}

Since $2004^{[1]}$, graphene has known a growing interest in numerous field of materials science. Indeed, its remarkable thermal, mechanical and electronic properties makes it a potential material for nano-electronic devices such as field effect transistors ${ }^{[2]}$, memory device ${ }^{[3]}$ or ultrafast laser $^{[4]}$. Besides, graphene possesses also a high surface area (up to $2630 \mathrm{~m}^{2} / \mathrm{g}$ ), easy bio-functionalization ${ }^{[5]}$ and a good biocompatibility ${ }^{[6]}$. These properties afford it a real potential for biotechnology applications, including biosensing device ${ }^{[7]}$, photothermal therapy ${ }^{[8]}$, drug delivery ${ }^{[9]}$, nanomedicine ${ }^{[10]}$, and cancer targeting ${ }^{[11]}$. To date, there are several known methods for preparing graphene ${ }^{[12]}$, including mechanical cleavage ${ }^{[13]}$ and chemical vapor deposition ${ }^{[14]}$. Chemically exfoliation of graphite gives graphene oxide generally in acidic ${ }^{[15]}$ or basic ${ }^{[16]}$ conditions. The chemical formation of reduced graphene oxide (CRGO) is the best method for large-scale production ${ }^{[17]}$ and the obtained nanomaterial possesses a large surface area compared to other forms of graphene ${ }^{[18]}$. The removal of oxygen and the recovery of aromatic double-bonded in chemical reduced graphene oxide restore the conductivity by several orders of magnitude ${ }^{[19]}$ as well as its electrochemical properties ${ }^{[20]}$.

Reduced graphene oxide (RGO) is hydrophobic and tends to agglomerate in water through strong $\pi-\pi$ stacking and van der Waals interactions ${ }^{[21]}$. As a consequence, considerable efforts have been made to improve its dispersion ${ }^{[22]}$. Chemical modification of RGO sheets or the entrapment of functional molecules has been performed for this purpose. For example, covalent functionalization of graphene sheets with various groups such alkyl azides ${ }^{[23]}$, porphyrins ${ }^{[24]}$ allowed a better dispersibility in organic solvents ${ }^{[23]}$. However, introduction of functional groups by covalent modifications creates $\mathrm{sp}^{3}$ carbon sites, compromising the $\mathrm{sp}^{2}$ structure of graphene and then the loss of its electronic properties. Noncovalent functionalization including $\pi-\pi$ interactions and van der Waals forces are preferred methods as it doesn't alter the $\pi$-conjugated structure and the electronic properties of graphene. Furthermore, this strategy allows the dispersion of the composite and affords news properties for further applications ${ }^{[25]}$. Various ionic ${ }^{[26]}$ and (or) aromatic molecules ${ }^{[27]}$ were 
investigated for their association with reduced graphene oxide such as poly(styrene sulfonate) ${ }^{[28-29]}$, quinoline $^{[30]}$, pyrene ${ }^{[31]}$, anthracene ${ }^{[32]}$ and bis(3,4-dihydroxybenzylidene)-1,2-diamino benzene Schiff base ligand ${ }^{[33]}$.

Porphyrins, due to their numerous chemical, electronic and optical properties, have been associated with conjugated nanomaterials such as graphene without covalent attachment ${ }^{[34]}$. Moreover, porphyrins can be easily modified with numerous groups, in various positions of the macrocycle, endowing additional properties, such as anionic or cationic form ${ }^{[35]}$. Numerous papers have described the formation of nanocomposite porphyrin/graphene ${ }^{[36]}$. The structure and electronic properties of the nanocomposite were demonstrated to be controlled by functional groups attached to the porphyrins ${ }^{[37]}$, the metal ion $^{[38]}$ as well as the structural properties of graphene ${ }^{[39]}$.

For example, tetra phenyl porphyrin bearing sulfonic acid was demonstrated to have a good association with reduced graphene and enhanced the dispersion due to the repulsive forces between the two materials ${ }^{[34]}$. However, cationic porphyrins such as 5,10,15,20-tetrakis(1-methyl-4-pyridinio) porphyrin could forms flattering complex through electrostatic interactions with chemically negatively charged graphene and leads to electronic modifications of such complex ${ }^{[40]}$. It was also demonstrated that electrostatic and $\pi-\pi$ staking interactions between charged porphyrins and graphene are controlled by functional groups on the surface of graphene and edge structure ${ }^{[41]}$. Therefore, the chemical structure of the porphyrin controls the mechanism of its association with the graphene nanosheets though, hydrogen bonding, ionic or $\pi-\pi$ staking interactions. Thus, the nature of the chemical structure of porphyrin rules the approach between the porphyrin plane and aromatic rings-based graphene as well as its association in the peripheries or the basal plane of graphene.

Nanocomposites formed between graphene and porphyrins have been demonstrated to bring new properties. They could be applied in various applications such as catalysis ${ }^{[42]}$, photocatalysis ${ }^{[43-44]}$, 
electrocatalytic $\mathrm{CO}_{2}$ conversion $^{[38]}$, sodium ion batteries ${ }^{[45]}$, sensors for various molecules and ions such as, explosive ${ }^{[46]}$, dopamine $e^{[47]}$, and immunosensors ${ }^{[48]}$.

Tetraphenylporphyrins, bearing carboxylic acid, have the advantage to introduce other molecules or biomolecules through chemical link. Their association with graphene allows the covalent attachment of DNA and their application in DNA sensing ${ }^{[49]}$. Thus, association of CRGO with such macromolecules bearing carboxylic acid constitutes an interest in biosensor devices. Here, we synthetized two modified teraphenylporphyrins (butyloxyphenylporphyrin) where phenyls were substituted in para position with one or four (carboxybutyloxy groups as donor substituents, to give a mono- or a tetra- carboxylic molecule $\left(\mathrm{H}_{2} \mathrm{TPP}-1 \mathrm{CP}\right.$ and $\mathrm{H}_{2} \mathrm{TPP}-4 \mathrm{CP}$, respectively, schema 1$)$. We studied their association with chemically reduced graphene oxide (CRGO) nanomaterial through UVvisible, FT-IR, Raman spectroscopy and MEB, SEM images to highlight the effect of specific side group on the structure of the nanocomposite. Electrochemical properties of the nanocomposites were also performed within inner sphere and outer sphere redox markers. The effect of chemical structure of the carboxyporphyrins in the mechanism of association with CRGO and thus their electrochemical properties was studied. We investigated this two nanomaterials H2TPP-nCP(n=1,2)/CRGO into DNA sensor and demonstrated their sensitivity and selectivity in PCR sample from M. Tuberculosis and resistant strand.

\section{Schema 1. Schematic representation of modified material}

\section{Results and discussions}

\subsection{Characterization of the nanocomposites by imaging}

The morphologies of the hybrid nanomaterials were characterized by SEM and AFM images (Figure 1). SEM images show that CRGO exhibits compact sheet with irregular layer and folding structure, where nano-sheets with many wrinkles and corrugation are observed (Figure 1A, image a). In the case of the hybrid nanomaterials, nano-sheet layers are observed with edge domains and thin 
and semitransparent flakes with less wrinkled textures compared to CRGO, (Figure 1A, images b, c). This demonstrates that anchoring the porphyrin to graphene leads to spacing CRGO nanosheets and form nano-sheets domain. The flakes of $\mathrm{H}_{2}$ TPP-1CP/CRGO fold together with ordered of 20-30 $\mu \mathrm{m}$ range and present crinkly sheets with more aggregation, compared to that of $\mathrm{H}_{2} \mathrm{TPP}-4 \mathrm{CP} / \mathrm{CRGO}$ with 5 to $10 \mu \mathrm{m}$ range. These results demonstrated that, the dispersion of CRGO was obtained with both porphyrins and was improved in the case of the association of $\mathrm{H}_{2} \mathrm{TPP}-4 \mathrm{CP}$ with CRGO (Figure 1A, image c), due to the presence of a highest number of carboxylic functions.

Figure 1. SEM (A) and AFM (B) images of (a) CRGO, (b) $\mathrm{H}_{2} \mathrm{TPP}-1 \mathrm{CP} / \mathrm{CRGO}$ and (c) $\mathrm{H}_{2} \mathrm{TPP}$ $4 C P / C R G O$.

AFM images confirm these results. Image of CRGO (Figure 1B, image a) displays flat surface and compact structure with a thickness of $6 \mathrm{~nm}$. This value is in the same order than that of RGO nanosheets (of $\sim 1 \mathrm{~nm})^{[50]}$. The reduction of the GO favors the multi-layer formation of sheets on the surface through a $\pi$ - $\pi$ stack. In the case of hybrid nanomaterials, dispersed nano-sheets of graphene were observed (Figure 1B, images b, c). The roughness factor measured of hybrid nanomaterial $\mathrm{H}_{2}$ TPP-1CP/CRGO is up to $250 \mathrm{~nm}$, because of the formation of small nano-sheet domains and edge plane (Figure $1 \mathrm{~B}$, image $\mathrm{b}$ ). In the case of nano-hybrid $\mathrm{H}_{2} \mathrm{TPP}-4 \mathrm{CP} / \mathrm{CRGO}$, the roughness factor is in the same order of magnitude than CRGO $(15 \mathrm{~nm})$ and differences between the edges of the sheets and the interior regions are also observed (Figure 1B, image c). This result suggests different associations behavior of the porphyrins with the surface of the reductive graphene oxide. Indeed, the two porphyrins interact with the basal plane of graphene through $\pi$-interaction due to their great conjugated structure similar to graphene. But in the case of $\mathrm{H}_{2}$ TPP-4CP porphyrin where the number of carboxylic groups are highest, hydrogen bonds with oxygen functions present on the peripheries of graphene could also be favored. 


\subsection{Spectroscopic characterization}

To underline the molecular and electronic properties of the nanocomposites, different techniques FT-IR, UV-Visible, Raman spectroscopies and XPS were performed.

The interactions between the porphyrins and graphene were analyzed by UV-visible experiments by successive addition of CRGO to constant solution of modified porphyrins (Figure $2 \mathrm{~A}, \mathrm{~B}$ ). After addition of CRGO, an increase of the Soret band intensity was observed at $417 \mathrm{~nm}$ resulting from the formation of the complex. This increase of absorbance is related to a better solubility of porphyrin after their attachment to CRGO. In fact, porphyrins bearing carboxylic group form aggregates due to the hydrogen bonding and when adsorbed on graphene their solubility increase enhancing the absorbance. A same behavior was observed after the interaction of the meso-tetra (4-carboxyphenyl) porphyrin with graphene ${ }^{[51]}$. The absence of red shift of Soret band underlines that any modification of porphyrin structure such as flattening was obtained as observed in some modified porphyrins ${ }^{[39]}$. The interaction of porphyrin with CRGO was analyzed using the Benesi-Hildebrand ${ }^{[52]}$ approach to determine the association constant. This model is generally used in the case of soluble or dispersed solution.

$$
\mathrm{k} \mathrm{H}_{2} \mathrm{TPP}-\mathrm{n}_{=1,4} \mathrm{C}+\mathrm{CRGO} \quad \gtrless \quad \mathrm{CRGO} /\left[\mathrm{H}_{2} \mathrm{TPP}-\mathrm{n}_{=1,4} \mathrm{C}\right]_{\mathrm{k}}
$$

where $\mathrm{k}$ is the number of porphyrins associated to CRGO graphene.

The association constant could be calculated following the equation equation (1):

$$
\frac{1}{\triangle D O}=\frac{1}{1 * \varepsilon_{417} * K_{a} * C_{H 2 T T P C^{*} C_{C R G O}}}+\frac{1}{\varepsilon_{417} * C_{H 2 T T P C}}(1)
$$

where $K_{a}$ denotes the apparent association constant, $\varepsilon_{417}$ is the molar absorption coefficient of complex porphyrin/CRGO and $\mathrm{C}_{\mathrm{H} 2 \mathrm{TPPC}}$ the porphyrin concentration. Inverse of the difference absorbance at 417 $\mathrm{nm}\left(1 / \Delta \mathrm{D}_{\mathrm{O}}\right)$ was plotted versus inverse of the CRGO concentration $\left(1 / \mathrm{C}_{\mathrm{CRGO}}\right)$ (Figure $\left.3 \mathrm{C}, \mathrm{D}\right)$. The apparent association constant of $\mathrm{H}_{2} \mathrm{TPP}-1 \mathrm{CP} / \mathrm{CRGO}$ and $\mathrm{H}_{2}$ TPP-4CP/CRGO was calculated to be (2.92 $\times 10^{4} \mathrm{M}^{-1}$ and $\left.8.93 \times 10^{4} \mathrm{M}^{-1}\right)$, respectively. These values are in the same order of magnitude of those demonstrated previous in the case of association of a cationic porphyrin, meso-tetrakis(4- $\mathrm{N}$ - 
methylpyridiniumyl)porphyrin, with RGO $3.1 \times 10^{4} \mathrm{M}^{-1}$ where stable dispersed complex are formed ${ }^{[53]}$. The difference of a factor of three between the mono and tetra substituted porphyrin can be attributed to the presence of highest number of carboxylic groups in $\mathrm{H}_{2} \mathrm{TPP}-4 \mathrm{CP}$ promoting the strongest hydrogen bonds association. This result demonstrates the strong interaction of $\mathrm{H}_{2} \mathrm{TPP}-1 \mathrm{CP}$ and $\mathrm{H}_{2}$ TPP-4CP to CRGO and the well dispersion properties of the composite.

Figure 2. UV-visible spectra recorded after successive addition of $1 \mathrm{mg} / \mathrm{mL} D M F$ solution of CRGO $\left((0,2,4,6,8,10,12,14,16,18\right.$, and $20 \mu \mathrm{L})$ to porphyrin solution $\left[(\mathrm{A}) \mathrm{H}_{2} \mathrm{TPP}-1 \mathrm{CP}\right.$ and $(\mathrm{B}) \mathrm{H}_{2} \mathrm{TPP}-$ $4 C P]$ in EtOH. (C, D) The affinity constant calculation.

The FT-IR of the composites were performed to analyze the mechanism of interaction between porphyrins and CRGO. FT-IR spectra (Figure 3A and 3B) exhibit two stretching vibration bands at around $1720 \mathrm{~cm}^{-1}$ and $1580 \mathrm{~cm}^{-1}$ corresponding to $\mathrm{C}=\mathrm{O}$ and $\mathrm{C}=\mathrm{C}$ bound, respectively. In comparison with the spectrum of porphyrin alone, a red shift of $\mathrm{C}=\mathrm{O}$ band by $20 \mathrm{~cm}^{-1}$ is noted in the both composites. This demonstrates hydrogen bonding formation between the porphyrin and graphene due to the presence of carboxylic function. In the case $\mathrm{C}=\mathrm{C}$ vibrations a shift of about $34 \mathrm{~cm}^{-1}$ (from 1611 to $1577 \mathrm{~cm}^{-1}$ ) is observed for $\mathrm{H}_{2}$ TPP-1CP/CRGO composite and $15 \mathrm{~cm}^{-1}$ (from $1602 \mathrm{~cm}^{-1}$ to $1587 \mathrm{~cm}^{-}$ ${ }^{1}$ ) for $\mathrm{H}_{2} \mathrm{TPP}-4 \mathrm{CP} / \mathrm{CRGO}$. This difference suggests that the aromatic carbon structure of $\mathrm{H}_{2} \mathrm{TPP}-1 \mathrm{CP}$ is more electronic influenced by the conjugated plane of CRGO than $\mathrm{H}_{2} \mathrm{TPP}-4 \mathrm{CP}$. Furthermore, the presence of only one functional group in $\mathrm{H}_{2} \mathrm{TPP}-1 \mathrm{CP}$ favors the interactions with the basal plane of the graphene through $\pi-\pi$ interactions due to some less steric effects. The distance between basal plane and macrocycle could be then lower compared to the $\mathrm{H}_{2}$ TPP-4CP (see, SI 2, Table S2).

Raman spectroscopy shows significant charge-transfer effects, through $\pi$-interactions between aromatic structure and the graphene basal plane. First, the variation of the intensity ratio of $I_{D} / I_{G}$ gives a good information of molecules association (where the D-band corresponds to $\mathrm{sp}^{3}$-hybridized carbon 
and the G-band to the vibration of $\mathrm{sp}^{2}$-bonded carbon atoms of graphene) (Figure 3C, a). The interaction of CRGO with $\mathrm{H}_{2}$ TPP-1CP or $\mathrm{H}_{2}$ TPP-4CP rises the intensity ratio of $\mathrm{I}_{\mathrm{D}} / \mathrm{I}_{\mathrm{G}}$ suggesting an increase of $\mathrm{sp}^{3}$ domain upon association of porphyrin. In addition, a downshift of the graphene G-band at $1600 \mathrm{~cm}^{-1}$ in the case of $\mathrm{H}_{2}$ TPP-1CP/CRGO and at $1596 \mathrm{~cm}^{-1}$ with $\mathrm{H}_{2} \mathrm{TPP}-4 \mathrm{CP} / \mathrm{CRGO}$ suggests $\pi$ interactions between porphyrin and CRGO. It is known that the G-band shifts to lower-frequencies or higher frequencies depending on the electronic properties of the aromatic molecules as donor or acceptor. Indeed, Müllen and Feng ${ }^{[27]}$ observed a downshift by $5 \mathrm{~cm}^{-1}$ of the G-band of graphene sheets after the attachment of electron-donor pyrene-1-sulfonic acid and an upshift after anchoring the electron acceptor perylene tetracarboxylic diimide bis-benzenesulfonic acid. In our case, the downshift observed for the $\mathrm{G}$ bands in nano-hybrids is related to electron donor properties of the two porphyrins due to the presence of alkoxy groups attached on the porphyrin macrocycles.

Figure. 3. FT-IR spectra of (a) CRGO, (b) $\mathrm{H}_{2} \mathrm{TPP}-n C P$, and (c) $\mathrm{H}_{2} \mathrm{TPP}-n C P / C R G O$ [(A) $\mathrm{H}_{2} \mathrm{TPP}-1 \mathrm{CP}$ and (B) $\left.\mathrm{H}_{2} \mathrm{TPP}-4 \mathrm{CP}\right]$ (C) Raman spectra of (a) CRGO, (b) $\mathrm{H}_{2} \mathrm{TPP}-1 \mathrm{CP} / \mathrm{CRGO}$ and (c) $\mathrm{H}_{2} \mathrm{TPP}-$ $4 C P / C R G O$ of powder

The modification of the fermi level of graphene could be also observed by XPS in C1s position. It was demonstrated that depending on the electron-donating or withdrawing groups, charge transfer leads to respectively upshifts or downshifts in $\mathrm{C}=\mathrm{C}$ peaks ${ }^{[54]}$. The devolution of $\mathrm{C} 1 \mathrm{~s}$ bands reveals mainly three components presented in CRGO films: $\mathrm{C}=\mathrm{C}$ at $284.6 \mathrm{eV}$, corresponding to $\mathrm{sp}^{2}$ carbon in the basal plane of graphene sheets, $\mathrm{C}-\mathrm{O}$ at $285.9 \mathrm{eV}$ and $\mathrm{C}=\mathrm{O}$ at $289.3 \mathrm{eV}$, coming from remained oxygen groups present in CRGO. Association with modified alkoxyphenyl-porphyrin with four carboxylic groups leads to upshifts in $\mathrm{C}=\mathrm{C}$ by $0.4 \mathrm{eV}$ (see SI 2.2, Figure S4). This variation corresponds to the charge transfer between the aromatic molecules and the graphene sheets and confirm the Raman results. The results obtained by spectroscopic analysis highlight that both porphyrins interact with graphene and have an effect in electronic properties of graphene. Electrochemical characterization is powerful methods to demonstrates such effect. 


\subsection{Electrochemical characterization}

\subsubsection{Characterization with external redox marker by cyclic voltammetry}

To check the electrochemical and surface properties of composite compared to CRGO, the electron transfer was analysis through redox properties of various external redox couples: $\left[\mathrm{Fe}(\mathrm{CN})_{6}\right]^{3-}$ 14-, $\left[\mathrm{Ru}\left(\mathrm{NH}_{3}\right)_{6}\right]^{2+/ 3+}$ and benzoquinone/hydroquinone. Inner-sphere redox marker $\left[\mathrm{Fe}(\mathrm{CN})_{6}\right]^{3-/ 4-}$, was used to inform of the chemical surface properties and the nanostructure of graphene. Ruthenium hexaamine, $\left[\mathrm{Ru}\left(\mathrm{NH}_{3}\right)_{6}\right]^{2+/ 3+}$ is an outer-sphere redox system, which is surface insensitive, and its redox properties and its electron transfer ability are influenced more likely by the density of electronics state (DOS) of the nanomaterials. Benzoquinone was also selected as a redox marker, because it is sensitive to proton transfer and informs on the ionic properties of the surface.

The electron transfer of the film of nanomaterials deposit onto GCE, was analyzed by cyclic voltammetry $(\mathrm{CV})$ in a solution containing the specific redox couple.

The electrochemical behavior of the composites was firstly performed with inner-sphere $\left[\mathrm{Fe}(\mathrm{CN})_{6}\right]^{3-/ 4-}$ (Figure 4A). The CVs show an increase of the $\Delta \mathrm{E}_{\mathrm{p}}$ of the redox marker of $117 \mathrm{mV}$ and $517 \mathrm{mV}$ for respectively composites associated $\mathrm{H}_{2}$ TPP-1CP and $\mathrm{H}_{2}$ TPP-4CP compared to CRGO. The redox process of the negatively charged redox marker becomes more difficult with the electrode surface due to the increase of the negative charges on the composite surface (from $\mathrm{H}_{2}$ TPP-1CP/CRGO to $\mathrm{H}_{2}$ TPP4CP/CRGO) that promotes electrostatic repulsions. Besides, to evaluate the effects of the proton exchange provided by the attached porphyrins onto the graphene surface, pbenzoquinone/hydroquinone redox couple was employed (Figure 4B). Small shift of oxidation potential is observed that demonstrated the lower effect of proton transfer from acidic porphyrins. Indeed, at a neutral $\mathrm{pH}$ range, the porphyrins are mostly in anionic forms.

When the outer sphere redox marker hexamine ruthenium, was employed, a remarkably higher electrochemical process and high reversibility is observed, particularly, for the hybrid $\mathrm{H}_{2} \mathrm{TPP}-$ 4CP/RGO nanomaterial (Figure 4C). Indeed, the ruthenium complex is sensitive to the density of 
electronics state of the graphene. This result underlines the electronic effect related to the alkoxy substituents attached to the porphyrins as electron-donating groups, and it is in good agreement of results obtained in Raman spectroscopic measurements and XPS.

Figure 4. $C V$ measurements of GCE modified electrodes with (solid curve) $C R G O$, (dot) $\mathrm{H}_{2} \mathrm{TPP}$ $1 \mathrm{CP} / \mathrm{CRGO}$, and (dash dot) $\mathrm{H}_{2} \mathrm{TPP}-4 \mathrm{CP} / \mathrm{CRGO}(\mathrm{A})$ in $5 \mathrm{mM}\left[\mathrm{Fe}(\mathrm{CN})_{6}\right]^{3-14-}(\mathrm{B})$ in $1 \mathrm{mM}$ benzoquinone and $(\mathrm{C})$ in $10 \mathrm{mM}\left[\mathrm{Ru}\left(\mathrm{NH}_{3}\right)_{6}\right]^{2+/ 3+}$, scan rate $50 \mathrm{mV} \mathrm{s}{ }^{-1}$

The kinetic of electron transfer $\left(\mathrm{k}_{\mathrm{s}}\right)$ with various redox markers could be measured following Nicholson method by measuring the peak-to-peak variation at various scan rate. This was achieved for all composites with the different redox probes to underline the relationships of structural effect on electronic properties (See SI 3.1 and SI 3.2 for details). The apparent coefficient diffusion (Do) of various electrolytes was also calculated to shows the ionic transfer on the different nanomaterials. The data are summarized in Table 1.

Table 1: Electrochemical parameters obtained for electrodes of various modifications

In the case of inner-sphere redox marker $\mathrm{Fe}(\mathrm{CN})_{6}^{3-/ 4-}$, the $k_{s}$ values were calculated to be $0.22 \mathrm{~cm} \mathrm{~s}^{-1}$ for CRGO, which is close to the value obtained for $\mathrm{RGO}^{[55]}$. The value decreased drastically with the two composites $\mathrm{H}_{2}$ TPP-1CP/CRGO and $\mathrm{H}_{2}$ TPP-4CP/CRGO to respectively 0.002 and $0.0003 \mathrm{~cm}$. $\mathrm{s}^{-1}$. This underlines the effect of negative charged coming from the carboxylate groups of the both porphyrins. The $\mathrm{k}_{\mathrm{s}}$ value, determined with benzoquinone/hydroquinone, shows small variation depending on the composites and proves that proton exchanged didn't take place between attached porphyrins and redox marker.

In the case of inner-sphere redox marker $\left[\mathrm{Ru}\left(\mathrm{NH}_{3}\right)_{6}\right]^{2+/ 3+}$, a small variation of ks was obtained for $\mathrm{H}_{2}$ TPP-1CP/CRGO composite compared to CRGO. However, an increase was observed for composite with $\mathrm{H}_{2}$ TPP-4CP/CRGO varying from 0.3 to $0.95 \mathrm{~cm} . \mathrm{s}^{-1}$. This result demonstrates clearly that the association of $\mathrm{H}_{2}$ TPP-4CP porphyrin with graphene has an electronic effect on the CRGO due to the 
presence of four donating alkoxy groups. This behavior supports the data obtained in Raman measurement and proves that the association of porphyrins with donating effect increases the density of electronic states of composite and then the fermi level.

The calculated diffusion coefficient remains the same with the composite $\mathrm{H}_{2} \mathrm{TPP}-1 \mathrm{CP} / \mathrm{CRGO}$ for all electrolyte and is much lower for the composite $\mathrm{H}_{2}$ TPP-4CP/CRGO (Table 1). This highlights that the permeability of the redox complex is impeded by the number of the functional group attached in lateral position of tetraphenyl porphyrin.

\subsubsection{Characterization through electrochemical impedance spectroscopy}

Electrochemical impedance measurement (EIS) was performed in PBS free of redox markers to underline the electrical properties of the composites. Results are shown in Figure 5 (see SI. 3.3 for details). The ESI data shows a lower impedance after $\mathrm{H}_{2} \mathrm{TPP}-1 \mathrm{CP}$ and $\mathrm{H}_{2} \mathrm{TPP}-4 \mathrm{CP}$ association which directly correlated to a decrease of the charge transfer $\left(R_{c t}\right)$. The value of $R_{c t}$ is down from $135 \mathrm{k} \Omega$ for CRGO to $73 \mathrm{k} \Omega$ and to $114 \mathrm{k} \Omega$ for respectively $\mathrm{H}_{2}$ TPP-1CP/CRGO and $\mathrm{H}_{2}$ TPP-4C/CRGO (Table S3). This indicates that the formation of hybrid nano-materials, with the association of $\mathrm{H}_{2} \mathrm{TPP}$, enhances the charge transfer process. Comparing the variation of $\mathrm{R}_{\mathrm{ct}}$ value between $\mathrm{CRGO}$ and $\mathrm{H}_{2} \mathrm{TPP}-4 \mathrm{CP} / \mathrm{CRGO}$, a small variation was observed. This can probably be attributed to less connection of dispersed nanosheets of nanohybrids. The values of capacitance were calculated from CPE (constant phase element) and could be directly related to the thickness of the nanocomposites (See detail of calculus in SI.3.3).

The thickness of CRGO was evaluated of $0.7 \mathrm{~nm}$ which is in agreement with compact structure. However, the value was calculated as $60 \mathrm{~nm}$ and $75 \mathrm{~nm}$, respectively for $\mathrm{H}_{2} \mathrm{TPP}-1 \mathrm{CP} / \mathrm{CRGO}$ and $\mathrm{H}_{2}$ TPP-4CP/CRGO.

Figure 5. Nyquist plots measured in PBS solution at applied potential $-0.3 \mathrm{~V}$ with Dc potential $10 \mathrm{mV}$ at frequency range $[0.01 \mathrm{~Hz}-100 \mathrm{KHz}]$ (a) CRGO, (b) $\mathrm{H}_{2} \mathrm{TPP}-1 \mathrm{CP} / \mathrm{CRGO}$ and (c) $\mathrm{H}_{2} \mathrm{TPP}-4 C P / C R G O$, Inset: equivalent circuit. $R$ s electrolyte solution resistance. 
From all these results, we can conclude that the electron transfer between the surface and the electrode is enhanced when these two porphyrins are attached to CRGO. In addition, attachment of porphyrins increase the nano-sheets domains factor compared to CRGO. These results underline also that the association of porphyrins with CRGO didn't follow the same mechanism for both porphyrins. $\mathrm{H}_{2}$ TPP-1CP and CRGO are associated through $\pi-\pi$ interactions between phenyl groups and $\pi$ conjugated CRGO basal plane, which presumably induce aggregates domains. However, $\mathrm{H}_{2} \mathrm{TPP}-$ 4CP/CRGO forms complex with more hydrogen bonds and should be attached more likely on the edge of graphene favoring nano-sheets structures. This latter is achievable thanks to the presence of oxygen functions on the peripheries of graphene. Similar interactions were also observed with the 5-(4hydroxyphenyl)-10,15,20-triphenylporphyrin with graphene oxide ${ }^{[56]}$. Thus, no effect on the electron transfer of redox marker p-benzoquinone/hydroquinone was observed and however, the negatively charges on the surface of graphene provided by porphyrins prevent electron transfer for negatively charged redox marker. Two mechanisms of the $\mathrm{H}_{2}$ TPP/CRGO association could be then proposed, where the $\mathrm{H}_{2}$ TPP-1CP and $\mathrm{H}_{2}$ TPP-4CP were associated through $\pi-\pi$ interactions of phenyl groups with the graphene sheet especially in the basal plane-like and the carboxyl groups interact through plane edge structure of graphene (Schema 2).

\section{Schema 2: General presentation of interactions}

In the case of electronics properties, it appears clearly from spectroscopic analysis and electrochemical measurements with outer-sphere redox marker that the density of fermi level of graphene are modified. This effect is higher in the case of the composite associated with $\mathrm{H}_{2} \mathrm{TPP}-4 \mathrm{CP}$. This can be explained by the presence of the large number of alkoxy chain attached to the tetraphenylporphyrin with donating effect favoring the increase of DOS in CRGO. The two 
nanocomposites are integrated into DNA sensors for electrochemical DNA detection and are compared.

\subsection{Application to DNA biosensors}

\subsubsection{Comparison of Detection of on $\mathrm{ssDNA} / \mathrm{H}_{2} \mathrm{TPP}-n C P / C R G O$}

The DNA biosensors, ssDNA/H 2 TPP-1CP/CRGO and ssDNA/H 2 TPP-4CP/CRGO were prepared. Single stranded DNA probes (ssDNA) were covalently attached to the porphyrin through an amide link between an amine in 5' position and the carboxylic groups of the mono or tetrakis(carboxylphenyl)porphyrin $\left(\mathrm{H}_{2} \mathrm{TPP}-1 \mathrm{CP} / \mathrm{CRGO}\right.$ or $\mathrm{H}_{2} \mathrm{TPP}-4 \mathrm{CP} / \mathrm{CRGO}$ complex) as described previously ${ }^{[49]}$.

Hybridization reaction was performed by successive addition of complementary targets (cDNA) onto ssDNA/ $\mathrm{H}_{2} \mathrm{TPP}-\mathrm{nCP} / \mathrm{CRGO}$ sensor. The evaluated concentrations of targets were ranging from 1 aM to $1 \mathrm{nM}\left(10^{-18} \sim 10^{-9} \mathrm{M}\right)$. Electrochemical detection of DNA targets was monitored by SWV in 1 $\mathrm{mM}$ benzoquinone (Figure $6 \mathrm{~A}, \mathrm{~B}$ ). The choice of the redox marker is related to its insensitive properties with the various modified surface as demonstrated in (2.3) and could inform on the hybridation reaction on the surface. After each addition of concentration of cDNA targets, the redox current of benzoquinone species into hydroquinone decreases whatever the nature of the biosensor. This electrochemical response is merely due to the formation of double-strand DNA structure on the electrode surface, which further blocks the diffusion of p-benzoquinone species onto the electrode. A plot of average current peak versus the concentration of complementary targets obtained for the two biosensors shows a significant variation with similar behavior (Figure 6C). Calibration curves show dynamic ranges from the concentration $10^{-18}$ to $10^{-12} \mathrm{M}$ for biosensor ssDNA/ $\mathrm{H}_{2} \mathrm{TPP}-1 \mathrm{CP} / \mathrm{CRGO}$ (Figure 6C, curve a) and from $10^{-18}$ to $10^{-11} \mathrm{M}$ for biosensors and ssDNA/H 2 TPP-4CP/CRGO (Figure 6C, curve b). The detection limit was calculated from linear part of the calibration curves and based to $\mathrm{S} / \mathrm{N} 3$, the value is $2 \times 10^{-18} \mathrm{M}$ for biosensor ssDNA/ $\mathrm{H}_{2} \mathrm{TPP}-1 \mathrm{CP} / \mathrm{CRGO}$ and $7 \times 10^{-19} \mathrm{M}$ for biosensor ssDNA/H $\mathrm{H}_{2} \mathrm{TPP}-4 \mathrm{CP} / \mathrm{CRGO}$. Thus, the two biosensors demonstrate high sensitivity to DNA 
hybridization thanks to electronic and structural properties provided by the composite, high electron transfer ability, large surface area and high loading ability for covalent attached bioreceptor provided by carboxyl function. The small variation in sensing properties obtained between the two biosensors could due probably to the number of carboxylic functions on the surface that rise the density of immobilized ssDNA. The reproducibility of the DNA hybridization platform was also tested with measurements with four independent biosensors. Each sensing layer was freshly prepared. A relative standard deviation (RSD) of 3\% value was estimated, which showed the high reproducibility of the biosensor layer.

The selectivity was evaluated by the detection of non-complementary target (nc-DNA) in all range of concentration and compared to results obtained in presence of complementary target (c-DNA) (Figure 7 D, E). A relative change of peak current in the case of the biosensor formed with $\mathrm{H}_{2}$ TPP1CP/CRGO is obtained with nc DNA (Figure 7D, curve b) compared to the result obtained with cDNA (Figure 7D, curve a). The average variation of $30 \%$ is obtained for larger concentration of ncDNA and since 10 atm notable variation in biosensor response was obtained with c-DNA compared to nc-DNA. This could be due to the non-specific adsorption of DNA to basal plane of graphene which remains non-modified by porphyrins. However, the biosensor formed with $\mathrm{H}_{2} \mathrm{TPP}-4 \mathrm{CP} / \mathrm{CRGO}$ shows smaller variation when hybridization occurs with nc-DNA target (Figure 7E), with less than $15 \%$ for higher concentration of nc-DNA target and distinguish variation since 1atm c-DNA target. This result can be explained by the large amount of carboxylate functions on phenyl groups of $\mathrm{H}_{2} \mathrm{TPP}-4 \mathrm{CP}$ porphyrin attached to CRGO that leads to a negatively charged surface preventing the non-specific interaction. Thus, the $\mathrm{H}_{2} \mathrm{TPP}-4 \mathrm{CP} / \mathrm{CRGO}$ nanomaterial appears as the best platform for limiting the non-specific interaction and with high sensitivity of detection where the atomolar concentration could be detected.

\subsubsection{Detection of PCR samples of M.tuberculosis and SNP mutation}

The polymerase chain reaction (PCR) samples of M.tuberculosis were composed of DNA fragment of 411 bases length from ropB gene with the wild-type sequence and mutated sequence with 
single nucleotide polymorphism (SNP) of TTG mutation. The hybridization reaction with the PCR sample with wild-type sequence (w-PCR) and the sample with TCG/TTG mutation (mt- PCR) were performed with the biosensor ssDNA/ $\mathrm{H}_{2} \mathrm{TPP}-4 \mathrm{CP} / \mathrm{CRGO}$ bearing wild-type ssDNA probe. The response of the biosensors after hybridization with the w-PCR sample and mt-PCR at $1 \mathrm{fM}$ concentration was performed by SWV (Figure 7A) and show that high variation is obtained with the complementary wt-PCR sequence compared to mt-PCR which present single mutation. Thus, hybridization with w-PCR sample leads to a decrease of current at $23 \pm 2.5 \%$, where hybridization with mt- PCR sample gives a small variation in current of $4 \pm 1.9 \%$ (Figure 7B).

These results demonstrate that biosensor based on $\mathrm{H}_{2} \mathrm{TPP}-4 \mathrm{CP} / \mathrm{CRGO}$ nanocomposite is able to measure DNA from PCR samples extracted from M.tuberculosis strains. The homogeneous distribution of ssDNA target on the surface allows the preparation of a high dense biosensor leading to high sensitivity at atomolar range. The residual negative charge on graphene surface provided by porphyrins prevent non-specific interactions without any other coating.

\section{Conclusion}

Carboxyalkoxyphenylporphyrins functionalized with one or four carboxylic groups were successfully synthesized and associated to CRGO by a simple and effective way. Stable association of CRGO with acidic alkoxyphenylporphyrins could be obtained, where the dispersion of CRGO as well as electronic properties are efficiently enhanced. We demonstrated that the association between $\mathrm{H}_{2}$ TPP-1CP and CRGO is performed through $\pi-\pi$ interactions between phenyl groups and graphene nano-sheet with formation of some aggregates. However, with the porphyrin bearing four carboxylic groups $\mathrm{H}_{2} \mathrm{TPP}-4 \mathrm{CP}$, the anchoring of the macrocycle is favored at the peripheries of the graphene, through hydrogen bonds with hydroxyl or carboxylic groups of RGO. This association is in favor of macrocycle attachment on the edge structure and improves the electronic properties of graphene. In this case, the $k s$ value of outer-sphere redox marker is arisen. Thus, we demonstrated that the non- 
covalent interactions between terta-phenylporphyrin bearing carboxylic groups and CRGO, lead not only to improve the dispersion and the electronic properties of CRGO but also allow the introduction of the functional groups on CRGO surface for further functionality. DNA biosensors was demonstrated and show that the nanocomposite formed with $\mathrm{H}_{2}$ TPP-4CP.CRGO leads to LOD of 1atm and high selectivity is obtained thanks to carboxylic group on the surface and efficient interaction of porphyrins which improved electronic properties. Detection of PCR sample of M.tuberculosis rpob gene and mutated with SNP was successfully demonstrated. Thus, this study highlights the interest of the CRGO modification by modified porphyrins and the role of the chemical function such as alkoxy group and carboxylate and their number to obtain nanomaterials with new properties.

\section{Experimental Section}

\section{Reagent}

Graphene oxide was purchased from Aldrich. All others reagents are purchased from SigmaAldrich France. DNA probe and target are shipped from Eurogentec France. DNA probe are modified with six carbonyl chain bearing amine group at terminal position.

The DNA sequence for probe, complementary and non-complementary are probe $\mathrm{NH}_{2}-\mathrm{C} 6-5$ ' TCA-ATC-TCG-GGA-ATC-TCA-ATG-TTA-G-3', complementary target 5'-CTA-ACATTG-AGA-TTC-CCG-AGA-TTG-A-3' and non-complementary 5'-CTA-ACA-TTGAGA-TTC-CGA-GAT-TGA-GAT-CTT-C-3'.

DNA probe specific for PCR products contained 18 bases with sequence is NH2-C6-5'CCGACT-GTT-GGC-GCT-GGG3'.

A thee-electrode cell was used and consisted of a glassy carbon electrode (GCE, $\left.0.071 \mathrm{~cm}^{2}\right)$ as working electrode, a platinum as counter-electrode and $\mathrm{Ag} / \mathrm{AgCl}$ as reference electrode. The redox marker solutions were prepared in $0.1 \mathrm{M}$ of $\mathrm{KCl}$ with $5 \mathrm{mM}\left[\mathrm{Fe}(\mathrm{CN})_{6}\right]^{3-/ 4}, 1 \mathrm{mM}$ benzoquinone and 10 $\mathrm{mM}\left[\mathrm{Ru}\left(\mathrm{NH}_{3}\right)_{6}\right]^{2+/ 3+}$. 


\section{Synthesis of 5-[4-(carboxylbutyloxy)phenyl]-10,15,20-triphenylporphyrin $\left(\mathrm{H}_{2} \mathrm{TPP}-1 \mathrm{CP}\right)$}

This compound was synthesized in one step from the diphenylporphyrin according to the literature as described in a previous paper ${ }^{[49]}$.

\section{Synthesis of 5,10,15,20-[4-(carboxylbutyloxy)phenyl]tetraphenylporphyrin $\left(\mathrm{H}_{2} \mathrm{TPP}-4 \mathrm{CP}\right)$}

The symmetrical tetraphenylporphyrin bearing four carboxylic groups $\left(\mathrm{H}_{2} \mathrm{TPP}-4 \mathrm{CP}, 9\right)$ is prepared from the 5,10, 15, 20-tetrakis ( $p$-methoxyphenyl)triphenylporphyrin (6) in three steps (Scheme 3) following the same procedure as $\mathrm{H}_{2}$ TPP-1CP. Due to the symmetry of the porphyrin (6), the strategy applied for the synthesis is Adler and Longo method, in one step via a condensation reaction from four equivalents of pyrrole units and four equivalents of p-methoxybenzaldehyde in propionic acid.

Schema 3. Synthesis of $\mathrm{H}_{2} \mathrm{TPP}-4 \mathrm{CP}$ (9) (i) $\mathrm{BBr}_{3}, \mathrm{DCM}, \mathrm{rt}, 18 \mathrm{~h}, 86 \%$; (ii) $\mathrm{CsCO}_{3}$, 5-bromovaleronitrile $\mathrm{DMF}, 60^{\circ} \mathrm{C}, 24 \mathrm{~h}, 34 \%$; (iii) dioxane, $\mathrm{HCl} 12 \mathrm{M}, 80^{\circ} \mathrm{C}, 12 \mathrm{~h}, 32 \%$

\section{5,10,15,20-(4- hydroxyphenyl) tetraphenylporphyrin (7)}

Boron tribromide (1.16mL, 22 eq.) was added at $0^{\circ} \mathrm{C}$ onto 5,10,15,20-(4-methoxyphenyl) tetraphenylporphyrin (6) (400 mg, $54 \mathrm{mmol}$ ) dissolved in $80 \mathrm{~mL} \mathrm{CH}_{2} \mathrm{Cl}_{2}$ under argon. The crude solution was mixed during 18 hours at room temperature. The solution was then basified with a saturated $\mathrm{Na}_{2} \mathrm{CO}_{3}$ solution and washed with water until the neutrality. The organic phase was then dried over $\mathrm{Na}_{2} \mathrm{SO}_{4}$ and concentrated to give $319 \mathrm{mg}(86 \%)$ of the crude product (7). Compound 7 was directly used in the next step without any purification. ${ }^{1} \mathrm{H} \mathrm{NMR}\left(250 \mathrm{MHz}, \mathrm{CDCl}_{3}\right): \delta 8.88(\mathrm{~m}, 8 \mathrm{H}$, pyrrol- $\left.H_{\text {meso }}\right), 8.24(\mathrm{~m}, 6 \mathrm{H}, \mathrm{Ar}-H), 8.07\left(\mathrm{~d},{ }^{3} \mathrm{~J}_{\mathrm{H}, \mathrm{H}}=8.5 \mathrm{~Hz}, 2 \mathrm{H}, \mathrm{Ar}-H\right), 7.80(\mathrm{~m}, 9 \mathrm{H}, \operatorname{Ar}-H), 7.12(\mathrm{~d}$, $\left.{ }^{3} \mathrm{~J}_{\mathrm{H}, \mathrm{H}}=8.25 \mathrm{~Hz}, 2 \mathrm{H}, \mathrm{Ar}-H\right),-2.06(\mathrm{ls}, 2 \mathrm{H}, \mathrm{NH})$.

\section{5,10,15,20-[4-(valeronitrile)phenyl] tetraphenyl-porphyrin $(8)$}

On a solution of porphyrin (7) $(50 \mathrm{mg}, 0.073 \mathrm{mmol}, 1 \mathrm{eq})$ in DMF (25 mL) was added $0.48 \mathrm{~g}$ $\mathrm{Cs}_{2} \mathrm{CO}_{3}(1.46 \mathrm{mmol}, 20 \mathrm{eq})$ under argon for stirring $2 \mathrm{~h}$ at room temperature. And then $0.17 \mathrm{ml}$ of $5-$ bromopentanenitrile was added (1.46 mmol, $20 \mathrm{eq})$ into the solution and the mixture was heated at 60 
${ }^{\circ} \mathrm{C}$ during 2 days. The solution was concentrated under vacuum and extracted with $\mathrm{CH}_{2} \mathrm{Cl}_{2}$ and washed with $\mathrm{H}_{2} \mathrm{O}$. The organic phase was then dried over $\mathrm{Na}_{2} \mathrm{SO}_{4}$ and concentrated to give $25 \mathrm{mg}(34 \%)$ of the crude product (8) and was directly used for the next step. ${ }^{1} \mathrm{H}$ NMR $\left(300 \mathrm{MHz}, \mathrm{CDCl}_{3}\right): \delta 8.87[8 \mathrm{H}, \mathrm{d}$, $\mathrm{J}=7.8 \mathrm{~Hz}], 8.24[6 \mathrm{H}, \mathrm{d}, \mathrm{J}=6.9 \mathrm{~Hz}], 8.14[2 \mathrm{H}, \mathrm{d}, \mathrm{J}=8.4 \mathrm{~Hz}], 7.77[9 \mathrm{H}, \mathrm{t}, \mathrm{J}=6.6 \mathrm{~Hz}, \mathrm{Ha}], 7.28[2 \mathrm{H}, \mathrm{d}, \mathrm{J}=6$ $\mathrm{Hz}], 4.3[2 \mathrm{H}, \mathrm{t}, \mathrm{J}=5.55 \mathrm{~Hz}], 2.6[2 \mathrm{H}, \mathrm{t}, \mathrm{J}=6.75 \mathrm{~Hz}], 2.19[4 \mathrm{H}, \mathrm{m}],-2.74[2 \mathrm{H}, \mathrm{s}] ;$ HRMS (MALDI- MS) $m / z$ calcd. for $\mathrm{C}_{64} \mathrm{H}_{58} \mathrm{~N}_{8} \mathrm{O}_{4}, \mathrm{M}=1002,45$, found 1002.47. FT-IR (ATR) $2093 \mathrm{~cm}^{-1}\left(v_{\mathrm{C} \equiv \mathrm{N}}\right)$.

\section{5,10,15,20-[4-(carboxylbutyloxy)phenyl] tetraphenyl-porphyrin (9)}

Nitrile was hydrolyzed by $\mathrm{HCl} 12 \mathrm{M}$ and afforded carboxylic porphyrin 9. On a solution of porphyrin (8) $(100 \mathrm{mg}, 0.1 \mathrm{mmol})$ in $4 \mathrm{~mL}$ dioxanne, was added $1.8 \mathrm{~mL}$ of a concentrated $\mathrm{HCl}$ solution. The reaction was running vigorously at $80{ }^{\circ} \mathrm{C}$ during 12 hours. Dichloromethane was added and the crude mixture was washed with water, dried over $\mathrm{Na}_{2} \mathrm{SO}_{4}$. Crude product was obtained with $32 \%$ of yield $(35 \mathrm{mg})$ as a pure powder. ${ }^{1} \mathrm{H} \mathrm{NMR}\left(300 \mathrm{MHz}, \mathrm{CDCl}_{3}\right): \delta 8.9[8 \mathrm{H}, \mathrm{m}] ; 8.3[6 \mathrm{H}, \mathrm{m}] ; 8.2$ $[2 \mathrm{H}, \mathrm{d}, \mathrm{J}=8.1 \mathrm{~Hz}] ; 7.8[9 \mathrm{H}, \mathrm{m}] ; 7.2[2 \mathrm{H}, \mathrm{d}, \mathrm{J}=7.5 \mathrm{~Hz}] ; 4.2[2 \mathrm{H}, \mathrm{t}, \mathrm{J}=4.8 \mathrm{~Hz}] ; 2.6[2 \mathrm{H}, \mathrm{t}, \mathrm{J}=6.9 \mathrm{~Hz}] ; 2.0$ $[4 \mathrm{H}, \mathrm{m}] ;-2.7[2 \mathrm{H}, \mathrm{s}, \mathrm{NH}]$. HRMS (APCI MS) $m / z$ calcd. for $\mathrm{C}_{64} \mathrm{H}_{62} \mathrm{~N}_{4} \mathrm{O}_{12},(\mathrm{M}+\mathrm{H})^{+} 1079.22$, found 1079.22. UV-vis spectrum in DMF: $\lambda_{\max }, 419 \mathrm{~nm} ; 515 \mathrm{~nm} ; 551 \mathrm{~nm} ; 592 \mathrm{~nm} ; 647 \mathrm{~nm}$.

\section{Preparation of $\mathrm{H}_{2}$ TPP/CRGO hybrid nanomaterial suspensions}

The CRGO investigated in this work was obtained by chemical reduction of graphene oxide in DMF according the method described by $\mathrm{Ai}$ and coll ${ }^{[18]}$. The characterization of the efficiency of reduction process was performed through XPS and Raman spectroscopy and was discussed in supplementary materials (See SI 1, Figure S1, Table S1 and Figure S2).

The designated CRGO solution was prepared by dispersing $1 \mathrm{mg}$ of CRGO (see synthesis in SI 1) in $1 \mathrm{~mL}$ DMF, and ultrasonicated for $1 \mathrm{~h}$. The $\mathrm{H}_{2} \mathrm{TPP}-1 \mathrm{CP}$ and $\mathrm{H}_{2} \mathrm{TPP}-4 \mathrm{CP}$ solutions were prepared by dispersing $0.1 \mathrm{mg}$ of porphyrins in $1 \mathrm{~mL} \mathrm{DMF}$, separately, and ultrasonicated for $30 \mathrm{~min}$. The hybrid nanomaterial was prepared by mixing a $0.1 \mathrm{mg} \cdot \mathrm{mL}^{-1}$ solution of porphyrin in a $1 \mathrm{mg} \cdot \mathrm{mL}^{-1}$ suspension of CRGO in DMF to obtain a ratio of $10 / 1$ (w/w) of CRGO/ $\mathrm{H}_{2} \mathrm{TPP}$. This ratio graphene-porphyrin was 
optimized to give the best sensitive surface as we demonstrated in our previous work ${ }^{[48]}$. The two kinds of porphyrin/CRGO nanomaterial suspensions, named $\mathrm{H}_{2} \mathrm{TPP}-1 \mathrm{CP} / \mathrm{CRGO}$ and $\mathrm{H}_{2} \mathrm{TPP}-$ 4CP/CRGO, were prepared by mixing $10 \mu \mathrm{L}$ of CRGO suspension $\left(1 \mathrm{mg} \cdot \mathrm{mL}^{-1}\right)$ and $10 \mu \mathrm{L}$ volume of $\mathrm{H}_{2}$ TPP-1CP and $\mathrm{H}_{2}$ TPP-4CP solutions $\left(0.1 \mathrm{mg} \cdot \mathrm{mL}^{-1}\right)$ separately to obtain 10:1 weight ratio of CRGO to porphyrin, followed by sonication for $30 \mathrm{~min}$.

\section{Construction of DNA biosensor}

A drop of $2 \mu \mathrm{L}$ of the prepared $0.1 \mathrm{mg} \mathrm{mL}^{-1} \mathrm{H}_{2}$ TPP-1CP/CRGO or $\mathrm{H}_{2}$ TPP-4CP/CRGO suspension was deposited onto the glassy carbon electrode surface followed by drying step under the lamp, and rinsing with distilled water. Finally, the $\mathrm{H}_{2} \mathrm{TPP}-1 \mathrm{CP} / \mathrm{CRGO}$ or $\mathrm{H}_{2} \mathrm{TPP}-4 \mathrm{CP} / \mathrm{CRGO}$ was activated in a freshly prepared $10 \mathrm{mM}$ solution ( $\mathrm{pH}=7.4) \mathrm{PBS}$ of $20 \mathrm{mM}$ EDC, $32 \mathrm{mM}$ NHS. The activation step was running for $1 \mathrm{~h}$ at room temperature. Then the electrode was immersed in $1 \mu \mathrm{M}$ solution of ssDNA probe prepared in PBS buffer for $1 \mathrm{~h}$ at room temperature. Subsequently, the obtained DNA sensor based on $\mathrm{H}_{2}$ TPP-1CP/CRGO or $\mathrm{H}_{2} \mathrm{TPP}-4 \mathrm{CP} / \mathrm{CRGO}$ was thoroughly rinsed with distilled water and stored in PBS at $4{ }^{\circ} \mathrm{C}$ before use. After each step of construction of the DNA sensor, the surface modifications were controlled by SWV method in benzoquinone.

\section{DNA hybridization}

The DNA hybridization of complementary 25-bases targets was performed by immersing each DNA sensor in solution of various concentration of DNA target of sequence model from hepatitis C gene for $40 \mathrm{~min}$ at $47^{\circ} \mathrm{C}$. The target concentrations were added successively from 1 aM, 10 aM, 100 aM, $1 \mathrm{fM}, 10 \mathrm{fM}, 100 \mathrm{fM}, 1 \mathrm{pM}, 10 \mathrm{pM}$ to $1 \mathrm{nM}$. After each incubation, the modified electrode was washed with distilled water for three times to eliminate no hybridized single strand DNA and then analyzed by SWV method in benzoquinone. The detection of non-specific interaction was conducted by immersing the electrode in solution of different concentration of non-complementary DNA target in PBS buffer from $1 \mathrm{aM}, 10 \mathrm{aM}, 100 \mathrm{aM}, 1 \mathrm{fM}, 10 \mathrm{fM}, 100 \mathrm{fM}, 1 \mathrm{pM}, 10 \mathrm{pM}$ to $1 \mathrm{nM}$ and incubated in the same conditions as for complementary target. To check the reproducibility, the experiment was 
repeated four times with freshly prepared biosensors individually.

\section{PCR samples detection}

The DNA from PCR samples was denaturized by heating at $95^{\circ} \mathrm{C}$ for $5 \mathrm{~min}$, and then immersed in an ice bath for $1 \mathrm{~min}$. The hybridization of wt- PCR samples and mut-PCR sample was performed by immersing the electrode previously modified with wt-DNA probe in solution of $1 \mathrm{fM}$ wt-PCR sample for $40 \mathrm{~min}$ at $47^{\circ} \mathrm{C}$. The same conditions were applied for the detection of the same concentration of mut-PCR.

\section{Methods}

FT-IR was performed by spectrometer Bruker FS66 equipped with ATR platinum Pike and MCT detector. UV-Visible spectra were realized with Spectrometer Carry and Raman spectroscopy was performed at room temperature with a Renishaw spectrometer, using a $532 \mathrm{~nm}$ laser physics argon laser focused on the sample with a DMLM Leica microscope with a 100x (NA=0.75) objective. XPS measurements were realised with a $\mathrm{K}$ Alpha spectrometer from Thermo-Fisher, using a monochromated X-ray Source (Al Ka, $1486.6 \mathrm{eV}$ ).

SEM images were recorded using a JEOL-2100F Scanning electron microscope and an internal charge coupled device (CCD) camera and AFM withTapping mode topography and phase imaging were accomplished using an Innova AFM Bruker with NanoDrive v8.02 software.

Electrochemical measurements were performed using an AUTOLAB PGSTAT 100 electrochemical analysis system controlled by NOVA software (Methrom). The three-electrode cell was purchased from BASI and consisted of glassy carbon electrode (GCE) (surface $0.071 \mathrm{~cm} 2$ ) as working electrode, a platinum as counter-electrode and $\mathrm{Ag} / \mathrm{AgCl}$ as reference electrode. The analysis was performed by electrochemical impedance spectroscopy (EIS) and cyclic voltammetry (CV).

\section{Acknowledgements}

The authors are grateful to the Chinese government and the university Paris-Saclay for financial support (Chinese Scolarship Council - No. 201408420128). The authors are grateful to Prof C. Sola 


\section{from I2BC University Paris-Saclay for providing PCR sample and Dr Ali Madouri from C2N CNRS for RAMAM analysis.}

\section{References}

[1] A. K. Geim and K. S. Novoselov, Nature materials. 2007, 6, 183.

[2] Y. M. Lin, C. Dimitrakopoulos, K. A. Jenkins, D. B. Farmer, H. Y. Chiu, A. Grill and P. Avouris, Science. 2010, $327,662$.

[3] E. B. Song, B. Lian, S. M. Kim, S. Lee, T.-K. Chung, M. Wang, C. Zeng, G. Xu, K. Wong, Y. Zhou, H. I. Rasool, D. H. Seo, H.-J. Chung, J. Heo, S. Seo and K. L. Wang, Appl Phys Lett. 2011, 99, 042109.

[4] Z. Sun, T. Hasan, F. Torrisi, D. Popa, G. Privitera, F. Wang, F. Bonaccorso, D. M. Basko and A. C. Ferrari, ACS Nano. $2010,4,803$.

[5] N. Mohanty and V. Berry, Nano Lett. 2008, 8, 4469.

[6] Y. Liu, D. Yu, C. Zeng, Z. Miao and L. Dai, Langmuir. 2010, 26, 6158.

[7] J. Gallego, J. Tapia, M. Vargas, A. Santamaria, J. Orozco and D. Lopez, Carbon. 2017, 111, 393.

[8] J. Li, X. Huang, R. Huang, J. Jiang, Y. Wang, J. Zhang, H. Jiang, X. Xiang, W. Chen, X. Nie and R. Gui, Carbon. 2019, 146, 660.

[9] X. Sun, Z. Liu, K. Welsher, J. T. Robinson, A. Goodwin, S. Zaric and H. Dai, Nano Research. 2008, 1, 203.

[10] H. Y. Mao, S. Laurent, W. Chen, O. Akhavan, M. Imani, A. A. Ashkarran and M. Mahmoudi, Chem Rev. 2013, $113,3407$.

[11] Q. Zhang, S. Deng, J. Liu, X. Zhong, J. He, X. Chen, B. Feng, Y. Chen and K. Ostrikov, Adv Funct Mater. 2019, $29,1805860$.

[12] S. Park and R. S. Ruoff, Nature Nanotechnology. 2009, 4, 217.

[13] M. G. Pastore Carbone, A. C. Manikas, I. Souli, C. Pavlou and C. Galiotis, Nature Communications. 2019, 10, 1572.

[14] A. Reina, X. Jia, J. Ho, D. Nezich, H. Son, V. Bulovic, M. S. Dresselhaus and J. Kong, Nano Lett. 2009, 9, 30.

[15] R. I. Jibrael and M. K. A. Mohammed, Optik. 2016, 127, 6384.

[16] K. S. Rao, J. Senthilnathan, Y.-F. Liu and M. Yoshimura, Scientific reports. 2014, 4, 4237.

[17] V. H. Pham, T. V. Cuong, S. H. Hur, E. Oh, E. J. Kim, E. W. Shin and J. S. Chung, J Mater Chem. 2011, $21,3371$.

[18] K. Ai, Y. Liu, L. Lu, X. Cheng and L. Huo, J Mater Chem. 2011, 21, 3365.

[19] H. Wang, H. W. Tian, X. Wang, L. Qiao, S. Wang, X. Wang, W. Zheng and Y. Liu, Chemical Research in Chinese Universities. $2011,27,857$.

[20] A. Shen, Y. Zou, Q. Wang, R. A. W. Dryfe, X. Huang, S. Dou, L. Dai and S. Wang, Angew Chem Int Ed. 2014, $53,10804$.

[21] S. Niyogi, E. Bekyarova, M. E. Itkis, J. L. McWilliams, M. A. Hamon and R. C. Haddon, J Am Chem Soc. 2006, $128,7720$.

[22] D. Wu, F. Zhang, H. Liang and X. Feng, Chem Soc Rev. 2012, 41, 6160.

[23] S. Vadukumpully, J. Gupta, Y. Zhang, G. Q. Xu and S. Valiyaveettil, Nanoscale. 2011, 3, 303.

[24] Y. Xu, Z. Liu, X. Zhang, Y. Wang, J. Tian, Y. Huang, Y. Ma, X. Zhang and Y. Chen, Adv Mater. 2009, $21,1275$.

[25] V. Georgakilas, J. N. Tiwari, K. C. Kemp, J. A. Perman, A. B. Bourlinos, K. S. Kim and R. Zboril, Chem Rev. 2016, 116, 5464.

[26] Y. Liang, D. Wu, X. Feng and K. Müllen, Adv Mater. 2009, 21, 1679.

[27] Q. Su, S. Pang, V. Alijani, C. Li, X. Feng and K. Müllen, Adv Mater. 2009, 21, 3191.

[28] J. Chen, J. Ge, L. Zhang, Z. Li, J. Li, Y. Sun and L. Qu, Microchimica Acta. 2016, 183, 1847.

[29] D. Yoo, J. Kim and J. H. Kim, Nano Research. 2014, 7, 717.

[30] J. Jing, Y. Zhang, W. Li and W. W. Yu, J Catal. 2014, 316, 174.

[31] S. Ghosh, X. An, R. Shah, D. Rawat, B. Dave, S. Kar and S. Talapatra, The Journal of Physical Chemistry C. 2012, 116, 20688.

[32] P. Khanra, M. E. Uddin, N. H. Kim, T. Kuila, S. H. Lee and J. H. Lee, RSC Advances. 2015, 5, 6443.

[33] I. Bravo, M. Revenga-Parra, K. Weber, J. Popp, F. Pariente and E. Lorenzo, Sensors and Actuators B: Chemical. 2018, $267,533$.

[34] J. Geng and H.-T. Jung, The Journal of Physical Chemistry C. 2010, 114, 8227.

[35] M. O. Senge, Acc Chem Res. 2005, 38, 733.

[36] Z. Yang, L. Fan, X. Fan, M. Hou, Z. Cao, Y. Ding and W. Zhang, Anal Chem. 2020.

[37] K. Ma, R. Wang, T. Jiao, J. Zhou, L. Zhang, J. Li, Z. Bai and Q. Peng, Colloids and Surfaces A: Physicochemical and Engineering Aspects. 2020, $584,124023$.

[38] K. Szkaradek, K. Buzar, E. A. Pidko and B. M. Szyja, ChemCatChem. 2018, 10, 1814.

[39] H.-C. Li, W. Jian, Y. Li, R. Jia, J. Wang, G.-J. Zhao, F.-Q. Bai and H.-X. Zhang, J Phys: Condens Matter. 2020, $32,155902$.

[40] Y. Xu, L. Zhao, H. Bai, W. Hong, C. Li and G. Shi, J Am Chem Soc. 2009, 131, 13490.

[41] T.-x. Ye, S.-1. Ye, D.-m. Chen, Q.-a. Chen, B. Qiu and X. Chen, Spectrochimica Acta Part A: Molecular and Biomolecular Spectroscopy. 2012, 86, 467.

[42] J. Choi, P. Wagner, R. Jalili, J. Kim, D. R. MacFarlane, G. G. Wallace and D. L. Officer, Advanced Energy Materials. $2018,8,1801280$.

[43] K. Hu, C. Chen, Y. Zhu, G. Zeng, B. Huang, W. Chen, S. Liu, C. Lei, B. Li and Y. Yang, J Colloid Interface Sci. 2019, $540,115$.

[44] Y. Chen, Z.-H. Huang, M. Yue and F. Kang, Nanoscale. 2014, 6, 978.

[45] N. A. Kumar, R. R. Gaddam, M. Suresh, S. R. Varanasi, D. Yang, S. K. Bhatia and X. S. Zhao, Journal of Materials Chemistry A. $2017,5,13204$.

[46] C. X. Guo, Y. Lei and C. M. Li, Electroanalysis. 2011, 23, 885. 
[47] S. Sakthinathan, H. F. Lee, S.-M. Chen and P. Tamizhdurai, J Colloid Interface Sci. 2016, 468, 120.

[48] J. Shu, Z. Qiu, Q. Wei, J. Zhuang and D. Tang, Scientific reports. 2015, 5, 15113.

[49] Y. Wang, H. Sauriat-Dorizon and H. Korri-Youssoufi, Sensors and Actuators B: Chemical. 2017, 251, 40.

[50] S. Stankovich, D. A. Dikin, R. D. Piner, K. A. Kohlhaas, A. Kleinhammes, Y. Jia, Y. Wu, S. T. Nguyen and R. S. Ruoff, Carbon. $2007,45,1558$.

[51] L. Wu, L. Feng, J. Ren and X. Qu, Biosens Bioelectron. 2012, 34, 57.

[52] H. A. Benesi and J. H. Hildebrand, J Am Chem Soc. 1949, 71, 2703.

[53] A. Wojcik and P. V. Kamat, ACS Nano. 2010, 4, 6697.

[54] H.-J. Shin, S. M. Kim, S.-M. Yoon, A. Benayad, K. K. Kim, S. J. Kim, H. K. Park, J.-Y. Choi and Y. H. Lee, J Am Chem Soc. 2008, $130,2062$.

[55] T. Sun, B. D. A. Levin, J. J. L. Guzman, A. Enders, D. A. Muller, L. T. Angenent and J. Lehmann, Nature Communications. $2017,8,14873$.

[56] R. Ge, X. Wang, C. Zhang, S.-Z. Kang, L. Qin, G. Li and X. Li, Colloids and Surfaces A: Physicochemical and Engineering Aspects. $2015,483,45$.

\section{List of Figures and Schemes}

Figure. 1. SEM (A) AFM (B) images of (a) CRGO, (b) $\mathrm{H}_{2} T P P-1 C P / C R G O$ and (c) $\mathrm{H}_{2} \mathrm{TPP}-$ $4 C P / C R G O$.
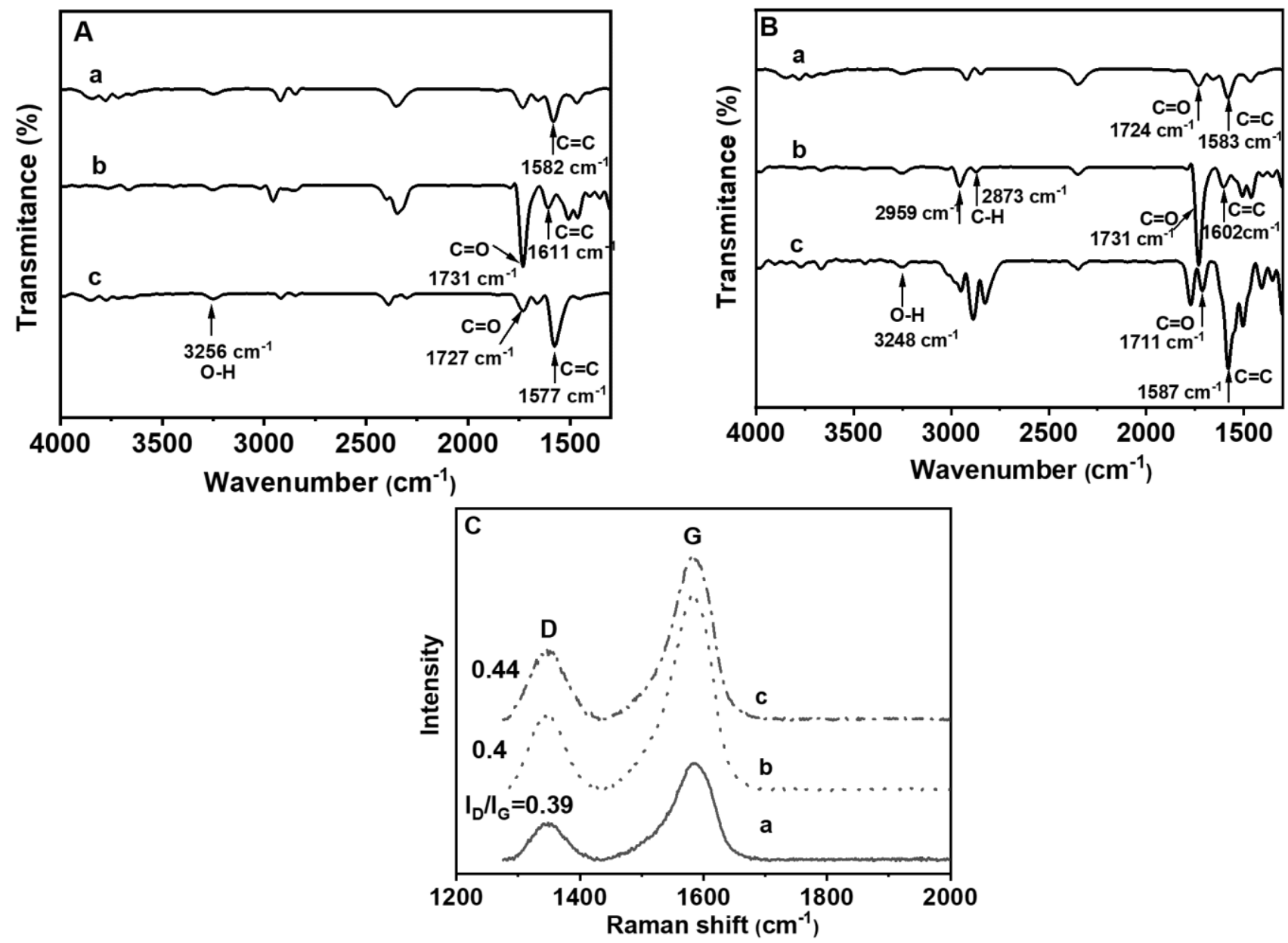

Figure. 2. FT-IR spectra, (A,B) Raman spectra, (C) of CRGO (a), $\mathrm{H}_{2} \mathrm{TPP}-1 \mathrm{CP}$ (b), and $\mathrm{H}_{2} \mathrm{TPP}$ - 
$1 C P / C R G O(c)$.

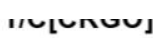

Figure. 3. $U V$-visible spectra recorded after successive addition $(0 \mu L, 2 \mu L, 4 \mu L, 6 \mu L, 8 \mu L, 10 \mu L$, $12 \mu \mathrm{L}, 14 \mu \mathrm{L}, 16 \mu \mathrm{L}, 18 \mu \mathrm{L}$, and $20 \mu \mathrm{L}$ ) of $1 \mathrm{mg} / \mathrm{mL} C R G O$ in DMF to porphyrin solution in ethanol [(A) $\mathrm{H}_{2}$ TPP-1CP and (B) $\mathrm{H}_{2}$ TPP-4CP]. (C, D) The curve of variation of optical density versus concentration of RGO for the complex with $\mathrm{H}_{2} T P P-1 C P(C)$ and $\mathrm{H}_{2} T P P-4 C P(D)$.

Figure 4. CV measurements of GCE modified electrodes with (solid curve) CRGO, (dot) $\mathrm{H}_{2} T P P$ $1 C P / C R G O$, and (dash dot) $\mathrm{H}_{2} \mathrm{TPP}-4 \mathrm{CP} / \mathrm{CRGO}(\mathrm{A})$ in $0.1 \mathrm{M} \mathrm{KCl}$ solution with $5 \mathrm{mM}\left[\mathrm{Fe}(\mathrm{CN})_{6}\right]^{3-14-}$ (B) in $1 \mathrm{mM}$ benzoquinone and $(\mathrm{C})$ in solution of $10 \mathrm{mM}\left[\mathrm{Ru}\left(\mathrm{NH}_{3}\right)_{6}\right]^{2+/ 3+}$, scan rate $50 \mathrm{mV} \mathrm{s} \mathrm{s}^{-1}$

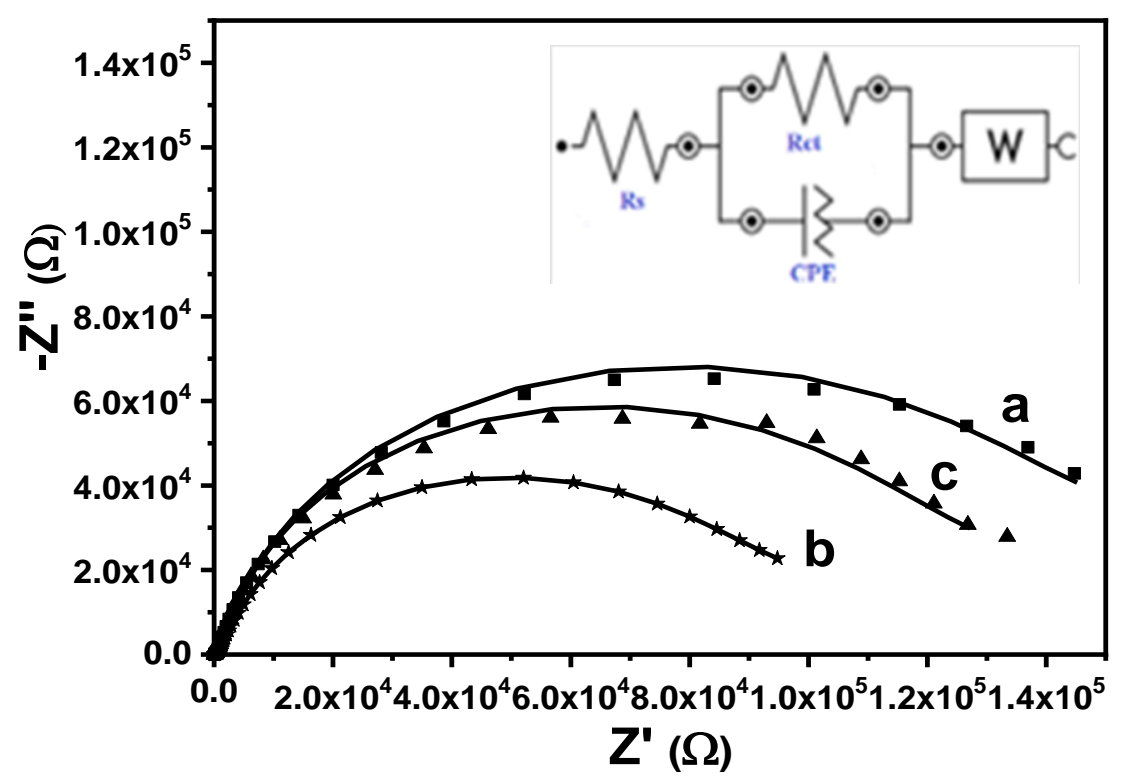

Figure 5. Nyquist plots measured in PBS solution at applied potential $-0.3 \mathrm{~V}$ with Dc potential $10 \mathrm{mV}$ at frequency range $\left[0.01 \mathrm{~Hz}-100 \mathrm{KHz}\right.$ (a) CRGO, (b) $\mathrm{H}_{2} \mathrm{TPP}-1 \mathrm{CP} / \mathrm{CRGO}$ and (c) $\mathrm{H}_{2} \mathrm{TPP}-4 \mathrm{CP} / \mathrm{CRGO}$, Inset: equivalent circuit used to model impedance data in the presence of redox couples. $R s$ electrolyte solution resistance, $R$ ct element of interfacial electron transfer resistance, CPE constant phase element.

Figure 6. $S W V$ experiments during detection of biosensors based on (A) $\mathrm{H}_{2} T P P-1 C P / C R G O$ and $(B)$ $\mathrm{H}_{2} \mathrm{TPP}-4 \mathrm{CP} / \mathrm{CRGO}$ at various concentration of targets (1 aM to $\left.1 \mathrm{nM}\right) ;(\mathrm{C})$ Plot of the relative changes of the current peaks versus concentration of DNA targets on the (a) $\mathrm{H}_{2} \mathrm{TPP}-1 \mathrm{CP} / \mathrm{CRGO}$ and (b) $\mathrm{H}_{2} \mathrm{TPP}-4 \mathrm{CP} / \mathrm{CRGO}$; Plot of the relative changes of the current peaks versus concentration of (a) 
complementary DNA and (b) non-complementary targets on the (D) $\mathrm{H}_{2} \mathrm{TPP}-1 \mathrm{CP} / \mathrm{CRGO}$ and $(E)$ $\mathrm{H}_{2}$ TPP-4CP/CRGO. Data points are the mean values \pm RSD obtained with four measurements.

Figure 7. Detection of wt PCR and mut PCR sequence in benzoquinone (A) SWVs measurements

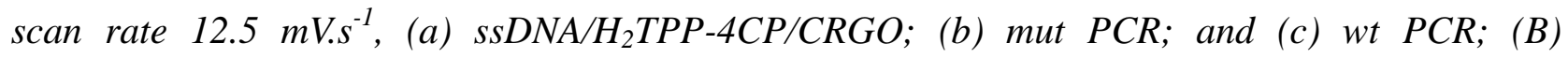
Histogram comparing hybridization signal intensities for detection of $1 \mathrm{fM}$ of wt PCR and mut PCR sample. Data points are the mean values $\pm R S D$ obtained with three independent experiments.

\begin{tabular}{|c|c|c|c|c|c|c|}
\hline & \multicolumn{2}{|c|}{$\mathrm{Fe}(\mathrm{CN})_{6}^{3-/ 4}$} & \multicolumn{2}{|c|}{ Benzoquinone } & \multicolumn{2}{|c|}{$\left[\mathrm{Ru}\left(\mathrm{NH}_{3}\right)_{6}\right]^{2+/ 3+}$} \\
\hline & $\begin{array}{c}\text { Do } \\
\left(10^{-6} \mathrm{~cm}^{2} \mathrm{~s}^{-1}\right)\end{array}$ & $\begin{array}{c}\mathrm{k}_{\mathrm{s}} \\
\left(\mathrm{cm} \cdot \mathrm{s}^{-1}\right)\end{array}$ & $\begin{array}{c}\text { Do } \\
\left(10^{-6} \mathrm{~cm}^{2} \mathrm{~s}^{-1}\right)\end{array}$ & $\begin{array}{c}\mathrm{k}_{\mathrm{s}} \\
\left(\mathrm{cm} \cdot \mathrm{s}^{-1}\right)\end{array}$ & $\begin{array}{c}\text { Do } \\
\left(10^{-6} \mathrm{~cm}^{2} \mathrm{~s}^{-1}\right)\end{array}$ & $\begin{array}{c}\mathrm{k}_{\mathrm{s}} \\
\left(\mathrm{cm} \cdot \mathrm{s}^{-1}\right)\end{array}$ \\
\hline CRGO & 5.43 & $\begin{array}{c}0.22 \\
\pm 0.02\end{array}$ & 1.17 & $\begin{array}{c}0.01 \\
\pm 0.001\end{array}$ & 8.96 & $0.3 \pm 0.03$ \\
\hline $\begin{array}{c}\mathrm{H}_{2} \text { TPP- } \\
\text { 1CP/CRGO }\end{array}$ & 6.11 & $\begin{array}{c}0.002 \\
\pm 0.0002\end{array}$ & 0.99 & $\begin{array}{c}0.02 \\
\pm 0.001\end{array}$ & 9.72 & $0.15 \pm 0.03$ \\
\hline $\begin{array}{c}\mathrm{H}_{2} \text { TPP- } \\
\text { 4CP/CRGO }\end{array}$ & 2.47 & 0.0003 & 0.56 & $\begin{array}{c}0.01 \\
\pm 0.001\end{array}$ & 3.92 & $0.95 \pm 0.02$ \\
\hline
\end{tabular}

Table 2: Electrochemical parameters obtained for redox marker analyzed with electrodes modified with various nanomaterials.

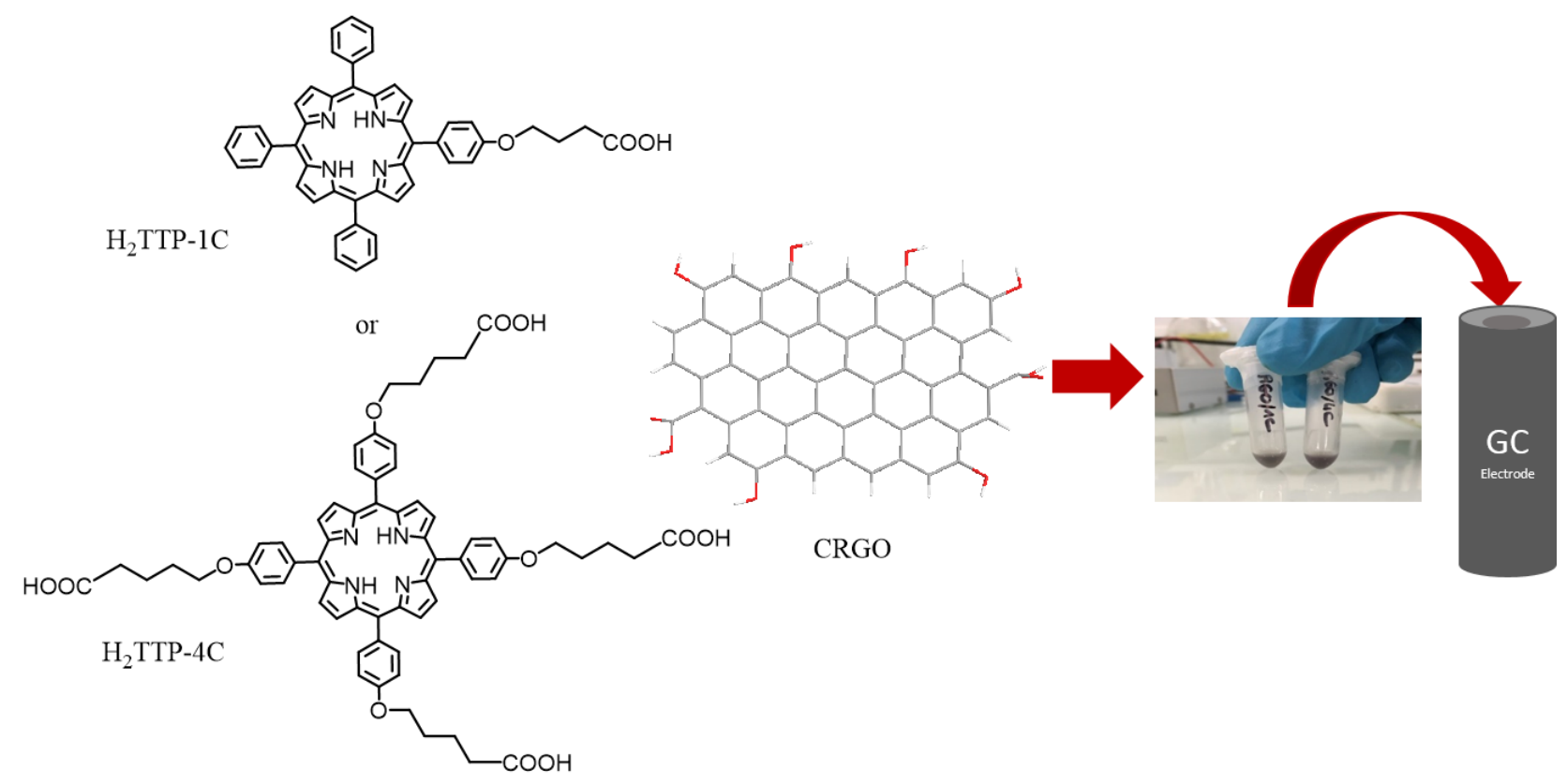

Schema 1. Schematic representation of modified material 
Schema 2: Schematic presentation of the interactions of modified porphyrins with RGO $\mathrm{R}=-\left(\mathrm{CH}_{2}\right)_{4}-\mathrm{COOH} \quad \mathrm{g}$

Schema 3. Synthesis of $\mathrm{H}_{2} \mathrm{TPP}-4 \mathrm{CP}$ (9) (i) $\mathrm{BBr}_{3}, \mathrm{DCM}, \mathrm{rt}, 18 \mathrm{~h}, 86 \%$; (ii) $\mathrm{CsCO}_{3}, 5$-bromovaleronitrile $\mathrm{DMF}, 60^{\circ} \mathrm{C}, 24 \mathrm{~h}, 34 \%$; (iii) dioxane, $\mathrm{HCl} 12 \mathrm{M}, 80^{\circ} \mathrm{C}, 12 \mathrm{~h}, 32 \%$ 